\title{
Performance Measures and Job Satisfaction: The Role of Fairness
}

\author{
Utami Puji Lestari ${ }^{1}$, Yusep Friya Purwa Setya ${ }^{2}$ \\ \{utami.lestari@akuntansi.pnj.ac.id ${ }^{1}$, yosep.friya@ akuntansi.pnj.ac.id² \\ Politeknik Negeri Jakarta, Indonesia ${ }^{1,2}$
}

\begin{abstract}
Employees tend to be more focus on a company's performance evaluation process, including the types of performance measures used by the company to measure its' employees performance. This is because the performance evaluation affects reward and compensation systems. The use of proper performance measures in the performance evaluation process would affect employees' performance, which in turn increasing the company's performance as a whole. It is expected that the use of financial and non-financial performance measures would affect job satisfaction. However, it is not clear whether this relationship is direct or not. The objective of this study is to investigate the mediating role of procedural and distributive fairness in the relationship between financial and non-financial performance measures and job satisfaction in the service industry. The data were collected from employees of accounting firms in Jakarta, Bogor, Depok, Tangerang, Bekasi, and Serang. Partial Least Square Structural Equation Modelling (PLS-SEM) was used to test the hypotheses. The results show that while the relationship between financial performance measures and job satisfaction is direct, the distributive fairness has a role in fully mediating the relationship between non-financial performance measures and job satisfaction in the service industry.
\end{abstract}

Keywords: Financial measures, job satisfaction, fairness

\section{Introduction}

Employees tend to be more focus on the company's performance evaluation procedure, comprising the types of performance measures used by the company to measure its' employees performance [1]. This is because the performance evaluation affects reward and compensation systems [2] [3]. The use of proper performance measures in the performance evaluation process would affect employees' performance, which in turn increases the company's performance as a whole.

This study investigates the effect of performance measures on job satisfaction - one of the employees' performances - by including the procedural and distributive fairness as the mediating variable. The reasons for the inclusion of fairness in this study are twofold. Previous studies have shown that fairness is an essential variable in the context of performance evaluation [1] [4] [5]. Moreover, Olowodunoye [6] mentioned that works in the area of organizational justice show that fairness may have an impact on the attitudes and behavior of managers. This study re-investigates the previous study by Lau and Sholihin [1] by examining the relationship between performance measures and job satisfaction, but in the context of the 
service industry. Moreover, this study extends Lau and Sholihin [1] by adding distributive fairness as one of the mediating variables.

The rest of the paper is organized as follows. The next section outlines the direct and indirect relationships among variables. It is followed by the explanation of the research method and statistical techniques used to test the hypotheses, a presentation of the results and a discussion of the main findings. The last section provides the conclusions and limitations of the study.

\section{Literature Review and Hypotheses Development}

\section{Performance Measures and Fairness}

There are two types of fairness: distributive fairness which means fairness of managerial decisions concerning the distribution of outcomes; and procedural fairness that represents the fairness of the procedures used to evaluate the outcome [7] [8] [9]. Perception of procedural fairness is affected by how someone is treated [8]: the procedure that can raise someone's role in an organization would be perceived as more fair than otherwise. The use of comprehensive performance measures, which include financial and non-financial aspects, would be perceived as fairer in the performance evaluation process as it represents the individual condition, that they each feel like a unique individual in the eyes of their superior [8] [10].

Accordingly, the following hypotheses are proposed:

$\mathrm{H} 1$ : The financial performance measures are significantly related to procedural fairness

$\mathrm{H} 2$ : The non-financial performance measures are significantly related to procedural fairness

H3: The financial performance measures are significantly related to distributive fairness

H4: The non-financial performance measures are significantly related to distributive fairness.

\section{Fairness and Job Satisfaction}

Employees' perception of their organizational fairness affects their work attitudes [11], such as job satisfaction [12]. Distributive fairness represents the perceived fairness of outcomes [9]. This kind of fairness will be perceived as fair by society if they perceive the procedure used to determine the outcome is sound [13]. If employees perceive both the procedure and the decisions related to the distribution of outcome as fair, they will be more loyal to the organization [14] [8], which in turn will affect their job satisfaction.

Therefore, the following hypotheses are proposed:

H5: The procedural fairness is significantly related to job satisfaction.

H6: The distributive fairness is significantly related to job satisfaction.

\section{Performance Measures and Job Satisfaction}

Comprehensive performance measures, which include effective training and development, employee involvement, job design, and reward systems, may improve employees organizational commitment [15], job satisfaction and motivation [16]. This is because a comprehensive performance measure is perceived as a more objective and more certain measure than only use financial measures [1]. This condition will lead to a higher trust of subordinates toward their superiors, which means lower stress and conflicts between them, that lead to higher job satisfaction [1].

These discussions suggest the following hypotheses:

H7: The financial performance measures are significantly related to job satisfaction.

H8: The non-financial performance measures are significantly related to job satisfaction.

\section{Methodology}

\subsection{Sample and Data Collection Procedure}

The data were collected from the employees at the senior level (senior auditors and supervisors) of accounting firms in Jakarta, Bogor, Depok, Tangerang, Bekasi, and Serang. These employees were considered to be the most appropriate person to provide information 
regarding financial and non-financial performance measures, procedural and distributive fairness and job satisfaction.

In total, 224 questionnaires, along with the cover letter that explains the aim of the study and the assurance of data confidentiality, were distributed to accounting firms via emails with Google Forms application to access the link of questionnaires. A total of 47 employees participated in this study resulting in an $18.3 \%$ response rate. This response rate is within the $10 \%-20 \%$ average response rate for surveys of respondent at the management level (Menon, Bharadwaj, \& Howell, 1996; Voola, Casimir, Carlson, \& Agnihotri, 2012). It also supports Gudono and Mardliyah [17] who suggest that the normal response rate of surveys in Indonesia is below 20\%. The participants' gender mix consisted of 12 females (25.53\%) and 35 male (74.47\%). Eight of the participants were part-time employees (17.02\%) while the other 39 were permanent employees (82.98\%). Most of the participants $(34.04 \%)$ have held their position for around 3 to 5 years; and they all held tertiary educational background, with most of them $(74.47 \%)$ have a bachelor degree.

Table 1. Factor Loading of Variables

\begin{tabular}{|c|c|c|c|c|c|c|c|}
\hline & $\begin{array}{l}\text { Distributive } \\
\text { fairness }\end{array}$ & Fin Perf & & $\begin{array}{c}\text { Job } \\
\text { satisfaction }\end{array}$ & $\begin{array}{c}\text { Procedural } \\
\text { Fairness }\end{array}$ & $\begin{array}{c}\text { Non- } \\
\text { Fin Perf }\end{array}$ \\
\hline DF 1 & 0.985 & & JS 1 & 0.931 & & NF 1 & 0.830 \\
\hline DF 2 & 0.980 & & JS 2 & 0.875 & & NF 2 & 0.717 \\
\hline DF 3 & 0.922 & & JS 3 & 0.959 & & NF 3 & 0.715 \\
\hline DF 4 & 0.907 & & JS 4 & 0.933 & & NF 4 & 0.771 \\
\hline DF 5 & 0.976 & & JS 5 & 0.928 & & NF 5 & 0.805 \\
\hline & & & JS 6 & 0.868 & & NF 6 & 0.708 \\
\hline F 1 & & 0.916 & PF 1 & & 0.910 & NF 7 & 0.703 \\
\hline F 2 & & 0.833 & PF 2 & & 0.942 & NF 8 & 0.836 \\
\hline F 3 & & 0.811 & PF 3 & & 0.966 & NF 9 & 0.670 \\
\hline & & & PF 4 & & 0.925 & & \\
\hline
\end{tabular}

\subsection{Measurement of Variables}

\subsubsection{Performance Measures}

These measures are adapted from a three-item financial performance measures instrument and nine-item non-financial performance measures instrument developed by Lau and Moser [8]. The respondents were requested to rate the importance of the items when their superior is evaluating their performance. All items of both financial and non-financial performance measures have satisfactory factor loadings; with minimum, loading is 0.81 for financial performance measures and 0.67 for non-financial performance measures. The Cronbach Alpha coefficients are 0.814 and 0.904 for the financial performance measures and non-financial performance measures, respectively.

\subsubsection{Fairness}

This measure was measured using the instrument developed by McFarlin and Sweeney [14] which consist of four items (for procedural fairness) and five items (for distributive fairness), seven-point Likert scale. Participants were asked to rate the fairness of the procedures used to evaluate their performance, and to rate the fairness of decisions about the distribution of rewards (e.g., payment and promotion). The loading of all items of procedural and distributive fairness instruments are satisfactory, with the minimum loading of 0.910 for procedural fairness and 0.907 for distributive fairness. The Cronbach Alpha coefficient for procedural fairness is 0.953 while distributive fairness has the coefficient value of 0.975 . 


\subsubsection{Job Satisfaction}

This variable was measured using six-item questionnaires developed by Rusbult and Farrel [18]. The participants were requested to rate the extent to which they agree with the statements about their jobs. The items of job satisfaction instrument have satisfactory loading values, with a minimum value of 0.868 . The Cronbach Alpha coefficient of this instrument is 0.962 .

Table 2. Construct Reliability and Validity.

\begin{tabular}{|l|c|c|c|c|}
\hline & $\begin{array}{c}\text { Cronbach's } \\
\text { Alpha }\end{array}$ & rho_A & $\begin{array}{c}\text { Composite } \\
\text { Reliability }\end{array}$ & AVE \\
\hline Distr. fairness & 0.975 & 0.980 & 0.981 & 0.911 \\
\hline Fin Perf & 0.814 & 0.812 & 0.890 & 0.730 \\
\hline Job satisfaction & 0.962 & 0.965 & 0.969 & 0.839 \\
\hline Non-Fin Perf. & 0.904 & 0.911 & 0.921 & 0.566 \\
\hline Procedural Fairness & 0.953 & 0.960 & 0.966 & 0.876 \\
\hline
\end{tabular}

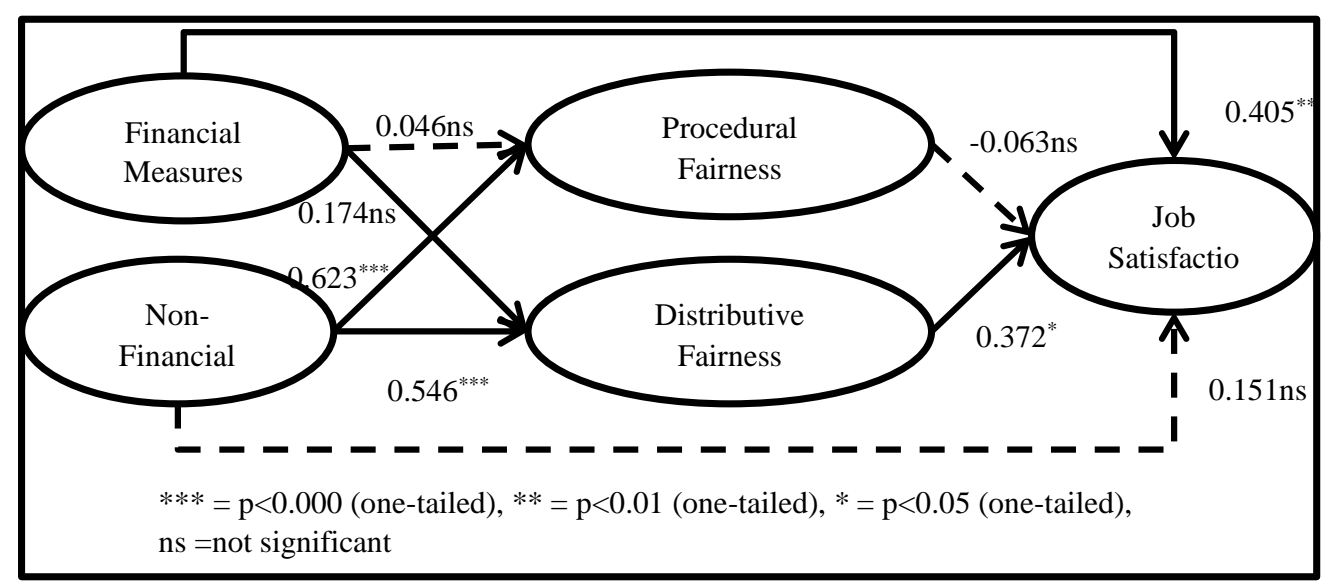

Figure 1. Structural Model Results.

\section{Results And Discussion}

This study used partial least squares structural equation modeling with SmartPLS® software [19] to test both the measurement model and the structural model. The results of the assessment of the structural model and hypotheses - using bootstrapping with 500 samples with replacement - show that the R2 of each dependent variable is more than 0.1 , which guarantee that variables explained by the dependent variables have significant practical and statistics. The detail of the R2 values can be seen in Table 3 below.

\subsection{Direct Effect}

The results in Figure 1 suggest that only H3, H4, H6, and H7 are significant under the onetailed test, which is used as the hypotheses are directional. $\mathrm{H} 3$ and $\mathrm{H} 4$ state that non-financial 
performance measures are significantly related to procedural fairness and distributive fairness, respectively.

Table 2. R Square Values

\begin{tabular}{|l|c|c|}
\hline & R Square & $\begin{array}{c}\text { R Square } \\
\text { Adjusted }\end{array}$ \\
\hline Distributive fairness & 0.447 & 0.421 \\
\hline Job satisfaction & 0.560 & 0.518 \\
\hline Procedural Fairness & 0.426 & 0.400 \\
\hline
\end{tabular}

Figure 1 shows that non-financial performance measures have a significant positive effect on procedural fairness $(0.623, \mathrm{p}<0.000$, one-tailed) and non-financial performance measures have a significant positive impact on distributive fairness $(0.546, \mathrm{p}<0.000$, one-tailed). Therefore, H3 and H4 are both supported. H6 states that distributional fairness is significantly related to job satisfaction. Figure 1 indicates that distributive fairness has a significant positive impact on job satisfaction $(0.372, \mathrm{p}<0.05$, one-tailed). Hence, H5 is supported. Finally, H7 states that financial performance measures are significantly related to job satisfaction. Figure 1 shows that financial performance measures have a significant positive effect on job satisfaction $(0.405, \mathrm{p}<0.01$, one-tailed $)$, which supported H7.

\subsection{Indirect Effect}

The results in Table 4 indicate that distributional fairness has a positive and significant mediating role in the relationship between non-financial performance measures and job satisfaction $(0.203, \mathrm{p}<0.1$, one-tailed). As there is no relationship between non-financial performance and job satisfaction, therefore the distributional fairness has a full mediating role in the relationship between non-financial performance measures and job satisfaction.

Table 4: Beta Coefficient, STDEV, T-Values, P-Values - Indirect Effect.

\begin{tabular}{|l|c|c|c|c|}
\hline & $\begin{array}{c}\text { Beta } \\
\text { Coeff. }\end{array}$ & $\begin{array}{c}\text { Std } \\
\text { Dev. }\end{array}$ & T Statistics & P Values \\
\hline $\begin{array}{l}\text { Fin Perf } \rightarrow \text { Distributive fairness } \rightarrow \\
\text { Job satisfaction }\end{array}$ & 0.065 & 0.080 & 0.816 & 0.207 \\
\hline $\begin{array}{l}\text { Non-Fin Perf } \rightarrow \text { Distributive } \\
\text { fairness } \rightarrow \text { Job satisfaction }\end{array}$ & 0.203 & 0.141 & 1.442 & 0.075 \\
\hline $\begin{array}{l}\text { Fin Perf } \rightarrow \text { Procedural Fairness }-> \\
\text { Job satisfaction }\end{array}$ & $\begin{array}{c}- \\
0.003\end{array}$ & 0.044 & 0.065 & 0.474 \\
\hline $\begin{array}{l}\text { Non-Fin Perf } \rightarrow \text { Procedural } \\
\text { Fairness } \rightarrow \text { Job satisfaction }\end{array}$ & $\begin{array}{c}- \\
0.039\end{array}$ & 0.148 & 0.264 & 0.396 \\
\hline
\end{tabular}

\section{Conclusion}

The objective of this study is to examine the intervening role of procedural and distributive fairness on the association between financial and non-financial performance measures and job satisfaction. The results clearly indicate that non-financial performance measures improve both procedural fairness and distributive fairness. Also, the results also indicate that financial performance measures directly affect job satisfaction, and distributional fairness fully mediates the association between non-financial performance measures and job satisfaction. 
This study adds to the literature of the management accounting in the following ways. This study was notifying the role and importance of the performance measures on the employees' job satisfaction. This study also confirms the role of fairness as an important aspect of performance evaluation. Specifically, this study support Sweeney and McFarlin [20] and Hartman, Yale and Galle [12] who argue that distributive fairness forecasts job satisfaction better than procedural fairness does. While the results of this study show that procedural fairness has no direct effect on job satisfaction, this result also provides empirical evidence that confirms the study of Lau, Wong, and Eggleton [21] who suggest procedural fairness affect job satisfaction indirectly through another aspect.

From a practical point of view, this study could be supportive of organizations. First, companies should concern not only to financial performance measures but also to nonfinancial performance measures used by them, as they would affect employees' job satisfaction. Second, the uses of non-financial performance measures are useful for organizations as they would improve employees' perception on both procedural and distributive fairness. Therefore, they should clearly specify and communicate these performance measures to their employees.

There are some limitations to this study. This study uses a small number of sample from one type of service industry. Future research could use a larger sample size and from some service industries to generalize the impact of this study. As the sample of this study was derived from private and service organization, the results may not be generalized to government organizations and manufacturing industry. Opportunities exist to re-examine our model in the context of government organization and manufacturing industry.

Moreover, there are several other variables omitted in this study that may affect the results. For example, as this study has used job satisfaction as the dependent variable; a future study could use another employee performance such as work performance, as it may also have an impact on the model. Also, a future study could add other mediating variables that may affect the relationship between performance measures and employee performance, for instance, organizational commitment.

\section{References}

[1] Lau, C. M. \& Sholihin, M. Financial and nonfinancial performance measures: How do they affect job satisfaction? The British Accounting Review, 37, 389-413. (2005)

[2] Langfield-Smith, K., Thorne, H. \& Hilton, R. 2012. Management accounting: Information for creating and managing value, Sydney Australia, McGraw_Hill Australia Pty Limited (2012)

[3] Nguyen, T. T., Mia, L., Winata, L. \& Chong, V. K. 2017. Effect of transformational-leadership style and management control system on managerial performance. Journal of Business Research, 70, 202-213 (2017).

[4] Sholihin, M., Pike, R. \& Mangena, M. The moderating effects of procedural fairness and distributive fairness on the relationaship between performance evaluation styles and job satisfaction. In: MANAGEMENT, B. U. S. O. (ed.). West Yorkshire (2007).

[5] Bol, J. C., Kramer, S. \& Maas, V. S. 2016. How control system design affects performance evaluation compression: The role of information accuracy and outcome transparency. Accounting, Organizations and Society, 51, 64-73.

[6] Olowodunoye, S. A. Knowledge sharing behaviour: the role of self-efficacy, organisational justice and organisational tenure. European Scientific Journal, ESJ, 11 (2015).

[7] Faizal, S. M. \& Palil, M. R. 2015. Study on Fairness and Individual Tax Compliance in Malaysia: Preliminary Findings. International Journal of Business, Economics and Law, 8, 74-79.

[8] Lau, C. M. \& Moser, A. Behavioral Effects of Nonfinancial Performance Measures: The Role of Procedural Fairness. Behavioral Research in Accounting, 20, 55-71 (2008). 
[9] Voußem, L., Kramer, S. \& Scaffer, U. 2016. Fairness perceptions of annual bonus payments: The effects of subjective performance measures and the achievement of bonus targets. Management Accounting Research, 30, 32-46

[10] Tan, S. L. C. \& Lau, C. M. 2012. The impact of performance measures on employee fairness perceptions, job satisfaction and organisational commitment JAMAR, 2, 57-72.

[11] Harrell-Cook, G., Levitt, K. \& Grimm, J. From Engagement to Commitment: A New Perspective on the Employee Attitude-Firm Performance Relationship. International Leadership Journal, 9 (2017).

[12] Hartman, S. J., Yrlea, A. C. \& Galle, J., W. P. Procedural and Distributive Justice: Examining Equity in a University Setting Journal of Business Ethics, 20 (1999).

[13] Farh, J.-L., Podsakoff, P. M. \& Organ, D. W. Accounting for Organizational Citizenship Behaviour: Leader Fairness and Task Scope versus Satisfaction. Journal of Management, 16, $705-$ 721 (1990).

[14] McFarlin, D. B. \& Sweeney, P. D. Distributive and procedural justice as predictors of satisfaction with personal and organizational outcomes. Academy of Management Journal, 35, 626-637 (1992).

[15] Camilleri, M. A. \& Camilleri, C. A. The Performance Management and Appraisal in Higher Education. In: ENGLAND, U. O. T. W. O. (ed.) Driving Productivity in Uncertain and Challenging Times. UK: British Academy of Management (2018).

[16] Tuan, V. K. \& Rajagopal, P. Analysis of managerial fators on the performance of small and medium-sized enterprises (SME) in manufacturing sector in Ho Chi Minh City - Vietnam. British Journal of Marketing Studies, 6, 26-51 (2018).

[17] Gudono, M. \& Mardliyah, A. A. The effect of task uncertainty, decentralization and management accounting characteristics on managers' performance. Journal of Indonesian Accounting Research, 4 (2000).

[18] Rusbult, C. E. \& Farrell, D.. A longitudinal test of the investment model: impact on job satisfaction, job commitment, and turnover variation in rewards, costs, alternatives, and investments. Journal of Applied Psychology 68, 429 - 438 (1983).

[19] Ringle, C. M., Wende, S. \& Becker, J.-M. SmartPLS 3. Bönningstedt: SmartPLS (2015)

[20] Sweeney, P. D. \& McFarlin, D. B. Workers' Evaluation of the "Ends" and the "Means": An Examination of Four Models of Distributive and Procedural Justice. Organizational Behavior and Human Decision Processes, 55, 23-40 (1993).

[21] Lau, C. M., Wong, K. M. \& Eggleton, I. R. C. Fairness of performance evaluation procedures and job satisfaction: the role of outcome-based and non-outcome-based effects. Accounting and Business Research, 38, 121-135 (2008). 